\title{
Production, Purification and Characterization of Extracellular Lipase from a Mutated Strain of Penicillium Citrinum KU613360 Lakkakula. Bhagya Lakshmi' ${ }^{1}$, M. Raghu Ram ${ }^{2}$
}

Freshman Engineering Department, Lakireddy Bali Reddy College of Engineering, Mylavaram, Krishna District, Andhra Pradesh, India ${ }^{1}$

Department of Botany and Microbiology, Acharya Nagarjuna University, Nagarjuna Nagar, Guntur District, Andhra Pradesh, India ${ }^{2}$

*Corresponding Author Email ID: mraghuram2002@gmail.com

Article Info

Volume 8, Issue 1

Page Number: 111-120

Publication Issue :

January-February-2021

\section{ABSTRACT}

In the present study lipase production, purification and characterization were carried out with a novel fungal strain of Penicillium citrinum KU613360 isolated from vegetable oil contaminated soil samples collected from oil mills located in and around Guntur District, Andhra Pradesh, India. The strain improvement was carried out by subjecting the strain to both UV and Ethidium Bromide treatments. The wild strain of P. citrinum KU613360 showed maximum lipase activity of $1.053 \pm 0.32 \mathrm{IUmL}-1$ on optimized medium and while the mutated strain treated with combination of UV (300 sec) and Et Br $(200 \mu \mathrm{gcm} 3)$, recorded the enzyme activity of $4.260 \pm 0.011 \mathrm{IUmL}-1$, using the optimised medium at $6.5 \mathrm{pH}$ and $40^{\circ} \mathrm{C}$ temperature. Thus, a $404 \%$ enhancement in the activity was achieved by using induced mutation on wild strain of P. citrinum KU613360. The molecular weight of the purified lipase from the mutated strain was found to be $35 \mathrm{kDa}$, when analysed on SDS PAGE. From our results it was concluded that the mutated strain has considerable

Article History

Accepted : 15 Jan 2021

Published : 25 Jan 2021 capability and potentiality to be used in various industrial applications.

Keywords : Lipase, Penicillium citrinum, mutated strains, Optimized medium, Lipase activity.

\section{INTRODUCTION}

Lipases have emerged as one of the important biocatalysts with explicit potential for contributing to the billion dollars under exploited lipid technology industry and have been utilized in situ metabolism of lipids and ex situ multipurpose industrial application ${ }^{[1]}$.
They are ubiquitous in nature habitat and are produced by numerous plants, animals and microorganisms [2]. Lipases belongs to the class of serine hydrolyses and do not require any cofactor and hydrolyses fats and oils to yield glycerol and free fatty acids [3]. Many microorganisms such as bacteria, yeast, moulds and 
few protozoans are known to secrete lipase from digestion of lipid materials $[4],[5]$.

Amongst the different microorganisms identified as source of lipase, filamentous fungi are believed as the excellent sources of extracellular lipase for mass production of industrial level. Many species belonging to Mucor, Rhizopus, Aspergillus, Geotrichum and Pencillium are broadly indentified as excellent sources of lipase [6],[7]. The abundant industrial applications of lipases have stirred interest in isolation of new lipases from novel sources and strong efforts have been concentrated on the engineering of enzyme with specific properties or better performance for industrial applications ${ }^{[8],[9]}$. Not only at the industrial application the lipase has gained has its significance in bioremediation processes in varied environment been well documented [10], [11]. Industrial and domestic wastes harbour fungal species of greater potential in degrading fats and oils. Besides waste disposal, bioconversions by fungal activities results in the production of vast number of useful substances. Thus, waste can be converted into a useful resource ${ }^{[12]}$. Bearing in mind the importance of extracellular lipolytic fungal enzymes, in the present study an attempt was made to produce a stabilized extracellular lipase with enhanced lipase activity from a novel Penicillium citrinum strain by mutational analysis and a comparative analysis was made on purification and characterization studies.

\section{MATERIALS AND METHODS}

\section{i) Microorganism and Lipase production}

The experimental fungal strain used in the present work was isolated by screening of soil samples collected from the oil spill mills near Guntur District, Andhra Pradesh, India on Olive oil-Rhodamine BAgar and tributryin Agar medium. The micro morphology of the isolated fungal strain was studied by viewing lactophenol cotton blue wet mount preparation. Based on the data, the isolate was assigned to the genus Penicillium. Confirmation of the assigned toxon was carried out using 18S r RNA gene sequence analysis.

The Sequencing analysis was carried out by Macrogen, South Korea. The sequence obtained was initially analyzed at National Center for Biotechnology Information (NCBI) server (http://www.ncbi.nlm.nih.gov) using Basic Local Alignment Search Tool (BLAST) and phylogenetic tree was constructed to identify the isolate. Based on the similarity studies, the sequence of the isolate was $97.4 \%$ similar to Pencillium citrinum. The sequence of the identified species, Penicillium citrinum, was deposited in Genbank with accession number KU613360.

\section{ii) Lipase assay:}

To verify the lipase activity, titrimetric assay was performed using olive oil as substrate by measuring the liberated fatty acid as described by Burket et al., [13] with few modifications. The reaction mixture $(5 \mathrm{ml})$ containing $1 \mathrm{ml}$ olive oil (emulsified with 7\% W/V gum Arabic in $50 \mathrm{mM}$ phosphate buffer $\mathrm{pH}$ 6.5) as substrate. The reaction was initiated by adding $1 \mathrm{ml}$ of appropriately diluted enzyme solution to the reaction mixture and incubated $15 \mathrm{~min}$ at temperature $37 \pm 2$ ${ }^{\circ} \mathrm{C}$. The reaction was stopped by adding of $15 \mathrm{ml}$ of acetone:ethanol $(1: 1 \mathrm{v} / \mathrm{v})$. The released free fatty acid was titrated with $0.05 \mathrm{~N} \mathrm{NaOH}$ to a thymolphttalein end point. Control was made with similar conditions without the inoculation of enzyme source. One IU of lipase was defined as the enzyme that liberates $1 \mu \mathrm{mol}$ of fatty acid per min at $37^{\circ} \mathrm{C} \pm 2, \mathrm{pH} 6.5$.

\section{iii) Strain improvement for enhanced Lipase production:}

a) Induced Mutagenesis by UV radiation:

The protocol described by Karanam et al., $2008^{[14]}$ was adopted with few minor changes. The spore suspension 
containing $1.5 \times 10^{5}$ conidia, obtained from 7 days old culture of parental strain ( $\boldsymbol{P}$. citrinum KU613360) was subjected for UV treatment. The experiment was carried out in a UV Illuminator fitted with $220 \mathrm{~V}, 40$ $\mathrm{W}, 50 \mathrm{~Hz}$ UV lamp and the strain was exposed to UV lamp from a distance of $15 \mathrm{~cm}$ away from the centre of the UV light source. The exposure time was kept 180sec and 300sec. The UV exposed spore suspension was stored in dark overnight to avoid photo reactivation. It was then serially diluted in phosphate buffer and plated on PDA medium. The inoculated petri dishes were incubated at $37 \pm 2^{\circ} \mathrm{C}$ for 7 days. The survived fungal colonies were isolated and the pure cultures are maintained on PDA slants, for further use.

\section{b) Induced Mutagenesis by Chemical Mutagen:}

The protocol described by Iftikhar et al., 2010 [15]with modifications was followed. A stock of $0.5 \mathrm{mg} \mathrm{mL}^{-1}$ Ethidium bromide was prepared. To the fungal spores (4.63 X $10^{7}$ spores $\left.\mathrm{mL}^{-1}\right) 9 \mathrm{~mL}$ of Vogel's medium was added along with ethidium bromide solution at concentrations of $100 \mu \mathrm{g} \mathrm{cm}^{-3}$ and $200 \mu \mathrm{g} \mathrm{cm}^{-3}$ separately and incubated at $37 \pm 2^{\circ} \mathrm{C}$ for $120 \mathrm{sec}$. It was then centrifuged three times at $10,000 \mathrm{rpm}$ for $15 \mathrm{~min}$., to remove the traces of mutagen. After adding few drops of buffer to the pellet, the treated spore suspension was made and inoculated on to PDA plates and incubated at $37 \pm 2^{\circ} \mathrm{C}$ for 7 days. The survived fungal colonies were isolated and the pure cultures are maintained on PDA slants, for further use.

\section{c) Combination of UV and EtBr treatment:}

To study the impact of dual treatments, the isolate was exposed to combined treatment of UV for time intervals of $180 \mathrm{sec}$. and $300 \mathrm{sec}$. and ethidium bromide for $120 \mathrm{sec}$. The treated spore suspension $(0.1 \mathrm{~mL})$ after different time intervals was transferred to PDA plates (4\%) having $1 \%$ oxgall as colony restrictor and incubated at $37^{\circ} \mathrm{C} \pm 2$ for $3-5$ days. The survived fungal colonies were isolated and the pure cultures are maintained on PDA slants, for further use.

\section{iv) Lipase production in optimized medium:}

The lipase production was estimated by growing the wild strain in the optimized medium containing Peptone $(0.7 \mathrm{gm})$, fructose $(0.5 \mathrm{gm})$ and inducers [Lin seed oil $(5.0 \% \mathrm{w} / \mathrm{v})]$, and substrate like NPP (pnitrophenyl Palmitate (C16:0), in presence of $2 \mathrm{mM}$ $\mathrm{Mn}^{2+}$ metal ion, incubated at a temperature of $40^{\circ} \mathrm{C}$ and $\mathrm{pH}$ of 6.5 for $96 \mathrm{hrs}$.

\section{v) Lipase enzyme extraction:}

The mutagen treated/survived culture was grown on PDA broth to obtain mycelial mat for further process. After 7 days of incubation the mycelia mat in the flask was subsequently filtered by using muslin cloth. The filtered mat was homogenised with $20 \mathrm{mM}$ phosphate buffer and centrifugation was carried out at 10000rpm for $20 \mathrm{~min}$. Further the culture filtrate was used as the crude enzyme source.

\section{vi) Purification of Lipase from mutant strain of $P$. citrinum KU613360:}

The purification of the lipase (Beisson et al., 2000) [16] was done by adopting three different steps like ammonium sulphate precipitation, Ion exchange chromatography (DEAE-Sepharose) and Gel chromatography (Sephacryl S-100 column). Ammonium sulphate was added to the culture broth up to $70 \%$ saturation, the solution was allowed to rest overnight at $4^{\circ} \mathrm{C}$ and then centrifuged at $10,000 \mathrm{x} g$ for 10 minutes. The resulting precipitate was dialyzed against distilled water for 48 hours at $4^{\circ} \mathrm{C}$. The product obtained was freeze dried and maintained at $10^{\circ} \mathrm{C}$. This freeze dried enzyme preparation was dissolved in sodium acetate buffer $(\mathrm{pH}=6.5 ; 50 \mathrm{mmol} / \mathrm{L})$ to a concentration of $50 \mathrm{mg} / \mathrm{mL}$, centrifuged at 10,000 x $g$ for 10 minutes and filtrate through acetate membrane 
with pore of $0.22 \mathrm{~mm}$. A pre-packed Q Sepharose fast flow column of $5 \mathrm{~mL}$ of internal volume, equilibrated with sodium acetate buffer $(\mathrm{pH}=6.5 ; 50 \mathrm{mmol} / \mathrm{L})$, was employed for the anionic exchange chromatographic step. The injection consisted of $1 \mathrm{~mL}$ of crude enzyme and elution was achieved using a non-linear $\mathrm{NaCl}$ gradient, with a final concentration of $1 \mathrm{~mol} / \mathrm{L}$ of the salt and a flow rate of $5 \mathrm{~mL} / \mathrm{min}$. Fractions of $5 \mathrm{~mL}$ were collected. Active fractions were pooled, dialyzed against water and freeze-dried. This partially purified lipolytic fraction was dissolved in sodium acetate buffer ( $\mathrm{pH}=6.5 ; 50 \mathrm{mmol} / \mathrm{L})$ containing $0.15 \mathrm{~mol} / \mathrm{L}$ $\mathrm{NaCl}$ to a concentration of $20 \mathrm{mg} / \mathrm{mL}$ and filtrated through acetate membrane (pore: $0.22 \mathrm{~mm}$ ). $5 \mathrm{~mL}$ of this preparation was loaded to a pre-packed Sephacryl S200 column $(2 \times 60 \mathrm{~cm}$, void volume of $120 \mathrm{~mL})$ for the gel filtration chromatographic step. The eluton flow rate was $0.3 \mathrm{~mL} / \mathrm{min}$ and fractions of $5 \mathrm{~mL}$ were collected.

\section{vii) Estimation of Protein:}

Protein was estimated by the method of Lowry et.al. (1951). To $0.1 \mathrm{ml}$ of the purified protein sample, 0.9 $\mathrm{ml}$ of distilled water and $5 \mathrm{ml}$ freshly prepared solution (100 $\mathrm{ml}$ of $2 \%$ sodium carbonate in $0.1 \mathrm{~N} \mathrm{NaoH}$ was mixed with $1 \mathrm{ml}$ of $2 \%$ sodium potassium tartrate and $1 \mathrm{ml}$ of $\mathrm{CuSO}_{4}$ ) were added. After 10 minutes at room temperature $0.5 \mathrm{ml}$ of diluted Folin- Ciocalteau reagent was added and mixed well. The intensity of the color was read at $660 \mathrm{~nm}$ against a reagent blank. A standard curve was prepared using Bovine serum albumin (BSA) as the standard (results not shown here). In the chromatography separation, the protein concentration in the fraction was routinely estimated by measuring the absorbance at $280 \mathrm{~nm}$.

SDS-PAGE was done to determine the Molecular Weight of lipase enzyme, following the method of Laemmli (1970). The gels were stained with Coomassie Brillant Blue R-250.

\section{RESULTS AND DISCUSSION}

\section{i) Lipase production in optimized medium:}

The wild strain of $\boldsymbol{P}$. citrinum KU613360 showed maximum lipase production when grown in a optimized medium containing (peptone $(0.7 \mathrm{gm})$, mixture of fructose $(0.5 \mathrm{gm})+$ inducers [Lin seed oil $(5.0 \% \mathrm{w} / \mathrm{v})]$, substrates [ $\mathrm{p}$-NPP (p-nitrophenyl Palmitate (C16:0)], metal ions [2 $\mathrm{mM}$ of $\mathrm{Mn}^{2+}$. at $\mathrm{pH}$ 6.5 and temperature $40{ }^{\circ} \mathrm{C}$ for 96 hrs. This strain recorded an increase in the activity from $0.147 \pm 0.004$ $\mathrm{IUmL}^{-1}$ in the basal medium to $1.053 \pm .032 \mathrm{IUmL}^{-1}$ in this optimized medium. Thus a 9 fold enhancement in the lipase activity (Table 1) was achieved by employing the optimized medium for lipase production by $\boldsymbol{P}$. citrinum. Lipase was found to be produced only in the presence of different oils indicating the inducible nature of the enzyme (Savitha et al., 2007) [19].

Table 1 : Comparative observations of Penicillium citrinum KU613360 strain in basal and optimized medium.

\begin{tabular}{|l|l|l|}
\hline \multicolumn{1}{|c|}{ Strain } & \multicolumn{1}{|c|}{ Basal Medium } & \multicolumn{1}{|c|}{$\begin{array}{c}\text { Optimized } \\
\text { Medium }\end{array}$} \\
\hline $\begin{array}{l}\text { Penicillium } \\
\text { citrinum } \\
\text { KU613360. }\end{array}$ & $\begin{array}{l}0.155 \pm 0.007 \\
\mathrm{IUmL}^{-1}\end{array}$ & $\begin{array}{l}1.053 \pm .032 \\
\text { (lipase activity) }^{-1} \\
\text { (lipase activity) }\end{array}$ \\
\hline
\end{tabular}

\section{ii) Strain Improvement:}

In the first step of induced mutagenesis, the experiment was conducted by exposing the wild strain of $\boldsymbol{P}$. citrinum to physical mutagen (UV rays) at $180 \mathrm{Sec}$ and $300 \mathrm{Sec}$ duration time. The subjected strain showed positive results by slight increase the lipase activity of $1.097 \pm 0.32$ and $2.013 \pm 0.13$ respectively over the wild strain. Similar findings were also reported in P.chrysogenum PCL 501 by OnyegemeOkerental et al., $2013^{[20]}$ and with Aspirgillus niger by

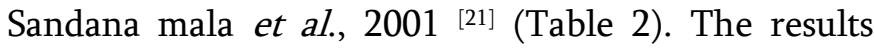


clearly indicated that the UV rays are potent physical mutagenic inducers to enhance the enzyme production. In the second step to verify and check the possibility of improving the strain further an attempt was made by treating the wild strain with chemical mutagen Ethidium Bromide (EtBr) in the concentrations of $100 \mu \mathrm{gcm}^{3}$ and $200 \mu \mathrm{gcm}^{3}$. The enhancement in lipase activity was found to be $2.067 \pm$ 0.05 and $2.150 \pm 0.21 \mathrm{IUmL}^{-1}$ respectively. In a desire to enhance the enzyme production still further induced mutagenesis analysis was carried out with a combination of treatments [UV (180 sec $)+\mathrm{EtBr}(100$ $\left.\mu \mathrm{gcm}^{3}\right)$ ], [UV $\left.(300 \mathrm{sec})+\operatorname{EtBr}\left(100 \mu \mathrm{gcm}^{3}\right)\right]$, [UV (180 $\left.\mathrm{sec})+\operatorname{EtBr}\left(200 \mu \mathrm{gcm}^{3}\right)\right]$, [UV (300 sec) + EtBr $(200$ $\left.\left.\mu \mathrm{gcm}^{3}\right)\right]$.The observation clearly indicated the enhancement in enzyme activity (Table 2). The best results were obtained in the combination of [UV (300 $\left.\mathrm{sec})+\operatorname{EtBr}\left(200 \mu \mathrm{gcm}^{3}\right)\right]$ with $4.260 \pm 0.11 \mathrm{IUmL}^{-1}$. When compared to control strain (wild strain $P$. citrinum ) the percentage increase in activity was 404 $\%$. Similar results were also reported by Bhaskaran et al (2018) in Aspergillus niger ${ }^{[22] . F o r m ~ o u r ~}$ experimental results it was clear that the impact of combinational mutagenesis was more effective and significant. Development of fungal strains for hyperproduction of lipase enzymes for biotechnological needs has been a hallmark in many industries processes (Karanam et al., 2008) [14]. The use of various physical and chemical mutagenic factors such as $\mathrm{UV}, \mathrm{HNO}_{2}$, NTG, Ethidium Bromide etc., for enhancement of lipase enzyme has been clearly demonstrated by many researchers (Bapiraju et al., 2004 [23]; Ahmed M ELBondkly and Abeer, $2007{ }^{[24]}$ ). Ellaiah et al ., 2002 reported a $200 \%$ enhancement in lipase activity by Aspergillus niger after treatment with UV and NTG [25]. Karanam et al (2008) also reported an increase in lipase production by $276 \%$ by strain improvement of indigenous isolate $A$. japonicus by $\mathrm{UV}, \mathrm{HNO}_{2}$ and NTG treatments. The results obtained in this mutagenesis analysis clearly demonstrated that the newly isolated mutated fungal strain Penicillium citrinum was much more flexible and selected mutant strain which was competitive and production increasing strain with optimized cultural parameters.

Table 2 : Chemical mutagenesis analysis for the Penicillium citrinum KU613360 and its mutant

\begin{tabular}{|c|c|c|c|c|}
\hline $\begin{array}{l}\mathrm{S} . \\
\mathrm{N} \\
\mathrm{O}\end{array}$ & $\begin{array}{l}\text { Volume } \\
\text { of } \\
\text { substrat } \\
\text { e Olive } \\
\text { oil } \\
(\mathrm{ml})\end{array}$ & $\begin{array}{l}\text { Condition } \\
\text { of } \\
\text { Mutagenesi } \\
\mathrm{s}\end{array}$ & $\begin{array}{l}\text { Lipase } \\
\text { activity } \\
\text { (IU/ml/min } \\
\text { ) }\end{array}$ & $\begin{array}{l}\text { \%Increas } \\
\text { e in lipase } \\
\text { activity } \\
\text { over the } \\
\text { control }\end{array}$ \\
\hline 1 & 1.0 & Control & $1.053 \pm 0.32$ & 100 \\
\hline 2 & 1.0 & $\begin{array}{l}\text { UV treated } \\
\text { for } 180 \mathrm{sec}\end{array}$ & $1.097 \pm 0.32$ & 104 \\
\hline 3 & 1.0 & $\begin{array}{l}\text { UV treated } \\
\text { for } 300 \mathrm{sec}\end{array}$ & $2.013 \pm 0.32$ & 191 \\
\hline 4 & 1.0 & $\begin{array}{l}\text { Et Br with } \\
100 \mu \mathrm{gcm}^{-3}\end{array}$ & $2.067 \pm 0.32$ & 196 \\
\hline 5 & 1.0 & $\begin{array}{l}\text { Et Br with } \\
200 \mu \mathrm{gcm}^{-3}\end{array}$ & $2.150 \pm 0.32$ & 204 \\
\hline 6 & 1.0 & $\begin{array}{l}\text { UV treated } \\
\text { for } 180 \mathrm{sec}+ \\
\text { Et } \mathrm{Br} \text { with } \\
100 \mu \mathrm{gcm}^{-3}\end{array}$ & $3.023 \pm 0.32$ & 287 \\
\hline 7 & 1.0 & $\begin{array}{l}\text { UV treated } \\
\text { for } 300 \mathrm{sec}+ \\
\text { Et } \mathrm{Br} \text { with } \\
100 \mu \mathrm{gcm}^{-3}\end{array}$ & $3.082 \pm 0.32$ & 292 \\
\hline 8 & 1.0 & $\begin{array}{l}\text { UV treated } \\
\text { for } 180 \mathrm{sec}+ \\
\mathrm{Et} \mathrm{Br} \text { with } \\
200 \mu \mathrm{gcm}^{-3}\end{array}$ & $4.016 \pm 0.32$ & 381 \\
\hline 9 & 1.0 & $\begin{array}{l}\text { UV treated } \\
\text { for } 300 \mathrm{sec}+ \\
\text { Et } \mathrm{Br} \text { with } \\
200 \mu \mathrm{gcm}^{-3}\end{array}$ & $4.260 \pm 0.32$ & 404 \\
\hline
\end{tabular}




\section{iii) Enzyme purification:}

Enzyme purification is a series of processes anticipated to isolate a single type of enzyme from complex mixtures. Success of enzyme purification scheme depends on the selection and effective combinations of different methodologies. In this study an attempt has been made to purify the lipase from novel mutated stain of $\boldsymbol{P}$. citrinum KU613360. The $1 \mathrm{ml}$ of mutant spore suspension, from a culture in PDA medium, after $72 \mathrm{hrs}$ incubation was inoculated into 1 liter of Erlenmeyer flasks containing optimized medium.These flasks were incubated at $40^{\circ} \mathrm{C}$ at $\mathrm{pH} 6.5$ for $120 \mathrm{hrs}$ and lipase produced was extracted with distilled water. The culture filtrate was used for the enzyme source for purification methods. After $120 \mathrm{hrs}$, the biomass in the medium was removed by centrifugation at $8000 \mathrm{X} \mathrm{g}$ for $15 \mathrm{~min}$ at $4{ }^{\circ} \mathrm{C}$ and supernatant obtained was subjected to $50 \%(\mathrm{w} / \mathrm{v})$ ammonium sulphate solution. The precipitate was allowed to stand at $4^{\circ} \mathrm{C}$ overnight, followed by another round of centrifugation at $8000 \mathrm{X} \mathrm{g}$ for $20 \mathrm{~min}$ at $4^{\circ} \mathrm{C}$. The precipitated pellet was dissolved in a minimal amount of $50 \mathrm{mM}$ Tris- $\mathrm{HCl}$ ( $\mathrm{pH}$ 6.5) containing $2 \mathrm{mM}$ benzamidine and dialysed for 24hrs. The crude enzyme obtained was quantified for total protein (mg) and its activity. It was observed that the crude enzyme showed 410mg of total protein content with $2117.0 \mathrm{IU}$ of activity (Table 3 ). As a second step of purification process the crude enzyme extract was subjected to another round of $70 \%$ ammonium sulphate. The lipase activity of about $1190 \mathrm{IU} / \mathrm{mg}$ was realized in $70 \%$ precipitation. The total protein yield was $27.8 \mathrm{mg}$. Thus 8.29 folds of purification were achieved by $70 \%$ ammonium sulphate precipitation. The lyophilized dried enzyme was dissolved in $50 \mathrm{mM}$ sodium acetate buffer ( $\mathrm{pH}$ 6.5) to a concentration of $50 \mathrm{mg} / \mathrm{ml}$ and was used as enzyme source for subsequent purification process. Generally no single chromatographic procedures are sufficient to obtain the requisite amount of purity of enzyme. Hence, combinations of chromatographic methods are necessary. Q-Sepharose was considered as the best method of ion-exchange chromatography for nearly $67 \%$ of purification (Saxena et al., 2003) [26]. The enzyme sample obtain in the process of $70 \%$ ammonium sulphate step was loaded on to Q-Sepharose column $(15 \mathrm{~cm} \mathrm{x} 1.6 \mathrm{~cm})$ previously equilibrated with $50 \mathrm{mM}$ sodium acetate buffer $\mathrm{pH}$ 6.5. The injection consisted of $50 \mathrm{ml}$ of enzyme source and eluted with a linear gradient of $\mathrm{NaCl}$ ranging from $0-1 \mathrm{M}$, prepared in the same buffer at a flow rate of $5 \mathrm{ml} / \mathrm{min}$. The $5 \mathrm{ml}$ fractions were collected and active fractions were pooled, dialyzed against distilled water and freeze dried. The protein and activity was determined. It was observed that the protein content was5.2 $\mathrm{mg}$ and $798.63 \mathrm{IU}$ and showed $153.58 \mathrm{IU} / \mathrm{mg}$ specific activity (Table 3 ). The partially purified lipase fractions was dissolved in sodium acetate $(\mathrm{pH} 6.5 ; 50 \mathrm{mmol} / \mathrm{L})$ containing $0.15 \mathrm{~mol} / \mathrm{L}$ $\mathrm{NaCl}$ to a concentration of $20 \mathrm{mg} / \mathrm{ml}$ and filtered through a biomembrane (pore: $0.22 \mathrm{~mm}$ ). $5 \mathrm{ml}$ of this concentrated enzyme was loaded onto Sephacryl S-200 $(93 \mathrm{~cm} \times 1.6 \mathrm{~cm})$ previously equilibrated with $50 \mathrm{mM}$ sodium acetate buffer $\mathrm{pH}$ 6.5. Elution was carried out with the same buffer at a flow rate of $15 \mathrm{ml} / \mathrm{h}$. The active enzyme fractions were pooled and analysed for their lipase activity and protein content. The specific activity was rose to $303.66 \mathrm{IU} / \mathrm{mg}$. The results showed that the total protein content was $1.9 \mathrm{mg}$ and lipase activity was 576.97 IU respectively. Thus by adopting this combination of chromatographic steps finally we have achieved 58.84 folds of purification and 9.7 of \% yield (Table 3). The relatively low yield can be ascribed to the fractionated desalting of the protein and the lipids partially aggregated with the enzyme [27]. Gombert et al., (1999) [28] studied the lipase production by Penicillium restrictum and reported the purity of 1,380 -fold with $27 \%$ recovery yield. The molecular weight of the enzyme was estimated to be 35,000 g/mol from Sephadex G-100 chromatography [28]. An extracellular lipase was purified from $P$. expansum PED-03 by DEAE-Sepharose, followed by 
Sephacryl S-200 .The enzyme purified 81.8 folds with 19.85 recovery and a specific activity of $85.94 \mathrm{U} / \mathrm{mh}$ was reported by Lianghua et al., 2007 [29]. P.candidum lipase was purified by Beatriz Ruiz etal., 2001[30] with 37 folds using Octyl-Sepharose CL-4B and DEAE Sephadex column .Similar results were previously reported on other Penicillium strains includes $P$. expansum DSM1994 [31], P.chrysogenum, P.cyclopium [32], Penicillium sp DS-39 (DSM23773) [33].

SDS PAGE analysis:

Molecular weight of the purified lipase from novel mutated stain of $P$. citrinum KU613360 was determined by SDS-PAGE on $12 \%$ polyacrylamide gel by using the standard protein markers of range 14.4 $94 \mathrm{kDa}$. The molecular mass was estimated by SDS PAGE analysis and was found to be $35 \mathrm{kDa}$ (Fig 1). In case of filamentous fungi, the molecular mass of lipases was basically in the range of $25 \mathrm{kDa}$ to $70 \mathrm{kDa}$ [3]. The molecular weight arrived in this investigation matches with that lipase from $P$. cyclopium ( $37 \mathrm{kDa}$ ) isolated by Chahinian et al., 2000[34] and other fungal sourcesRhizopus oryzae (35kDa) (Miklos Tako et al., 2017 [35] and Aspergillus niger $35.5 \mathrm{k}$ Da (Namboodiri and Chattopadhyaya, 2000 [36].

Table 3 : Purified Lipase analysis for mutant strain of Penicillium citrinum

\begin{tabular}{|l|l|l|l|l|l|}
\hline $\begin{array}{l}\text { Purificat } \\
\text { ion steps }\end{array}$ & $\begin{array}{l}\text { Total } \\
\text { prot } \\
\text { ein } \\
\text { (mg) }\end{array}$ & $\begin{array}{l}\text { Total } \\
\text { activ } \\
\text { ity } \\
\text { (IU) }\end{array}$ & $\begin{array}{l}\text { Speci } \\
\text { fic } \\
\text { activi } \\
\text { ty } \\
\text { (IUm } \\
\left.\mathbf{g}^{-1}\right)\end{array}$ & $\begin{array}{l}\text { Purifica } \\
\text { tion } \\
\text { (fold) }\end{array}$ & $\begin{array}{l}\text { Yeild( } \\
\%)\end{array}$ \\
\hline $\begin{array}{l}\text { Crude } \\
\text { extract }\end{array}$ & 410 & $\begin{array}{l}2117 . \\
0\end{array}$ & 5.16 & 1 & 100 \\
\hline $\begin{array}{l}\text { Ammon } \\
\text { ium }\end{array}$ & 27.8 & 1190 & 42.80 & 8.29 & 85 \\
\hline
\end{tabular}

\begin{tabular}{|l|l|l|l|l|l|}
\hline $\begin{array}{l}\text { sulphate } \\
(70 \%)\end{array}$ & & & & \\
\hline $\begin{array}{l}\text { Q- } \\
\text { Sepharo } \\
\text { se }\end{array}$ & 5.2 & $\begin{array}{l}798.6 \\
3\end{array}$ & $\begin{array}{l}153.5 \\
8\end{array}$ & 29.76 & 52 \\
\hline $\begin{array}{l}\text { Sephacr } \\
\text { yl-200 }\end{array}$ & 1.9 & $\begin{array}{l}576.9 \\
7\end{array}$ & $\begin{array}{l}303.6 \\
6\end{array}$ & 58.84 & 9.7 \\
\hline
\end{tabular}

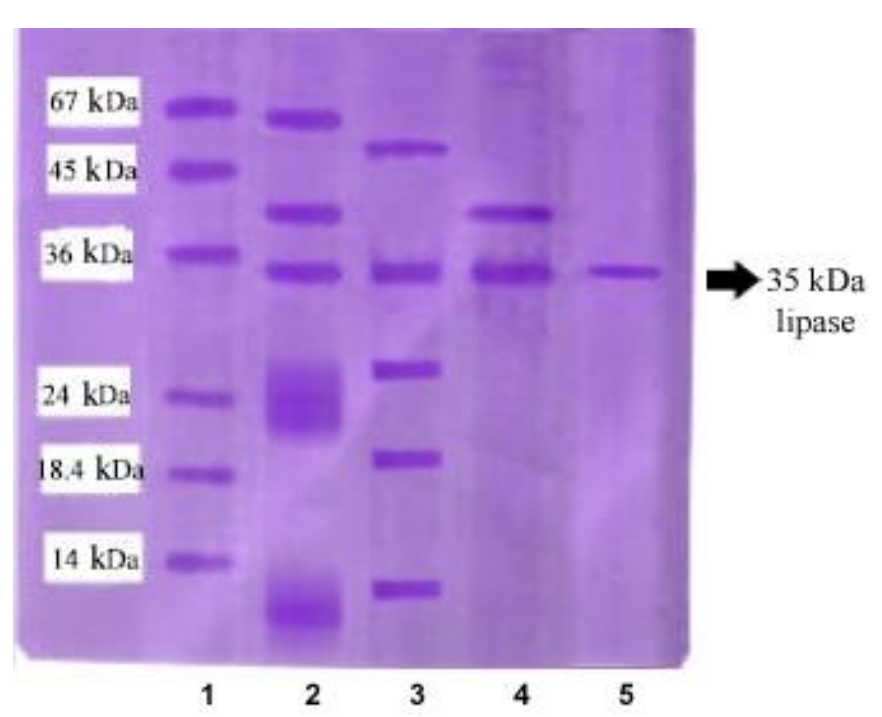

Fig 1 : Analysis of purified Lipase on SDS-PAGE gel Lane 1: Marker; Lane 2 : Crude extract; Lane 3 : Ammonium sulphate purification; Lane 4: QSepharose; Lane 5 : Sephacryl - 100

\section{CONCLUSION}

An extracellular lipase produced by mutant strain of Penicillium citrinum KU613360. was purified by ammonium sulphate precipitation and gel chromatography with molecular weight of $35 \mathrm{kDa}$, purified lipase found maximum activity at $40^{\circ} \mathrm{C}$ with optimum $\mathrm{pH}$ at 6.5 and metal ion $\mathrm{Mg}^{2+}$ has $100 \%$ relative activity providing stability to the lipase. We have successfully developed a promising mutant strain, by employing a simpler technique of chemical mutagenesis, which can be exploited at bioreactor level for industrial production of lipase, a biotechnologically important hydrolytic enzyme. The result of the present study indicates that the mutant P. citrinum KU613360 
strain is a potential lipase producing strain that can be efficiently utilized in detergent industry.

\section{ACKNOWLEDGEMENTS}

One of the Authors (Lakkakula Bhagya Lakshmi) is thankful to the Principal, Management of Lakireddy Bali Reddy College of Engineering, Mylavaram and Head, Department of Botany and Microbiology, Acharya Nagarjuna University (ANU), for their constant support, guidance for doing the present work and providing necessary facilities to complete this research work.

\section{REFERENCE}

[1]. Ray, S., 2015. Applications of extracellular microbial lipases-a review. Int J Res Biotechnol Biochem, 5(1), pp.6-12.

[2]. Thakur, S., 2012. Lipases, its sources, properties and applications: a review. Int J Sci Eng Res, 3(7), pp.1-29.

[3]. Singh AK, Mukhopadhyay M. Overview of fungal lipase: a review. Applied biochemistry and biotechnology. 2012 Jan 1;166(2):486-520.

[4]. Ginalska, G., Bancerz, R. and KorniłłowiczKowalska, T., 2004. A thermostable lipase produced by a newly isolated Geotrichum-like strain, R59. Journal of Industrial Microbiology and Biotechnology, 31(4), pp.177-182.

[5]. Carvalho, P.D.O., Calafatti, S.A., Marassi, M., Silva, D.M.D., Contesini, F.J., Bizaco, R. and Macedo, G.A., 2005. Potential of enantioselective biocatalysis by microbial lipases. Quimica Nova, 28(4), pp.614-621.

[6]. Contesini, F.J., Lopes, D.B., Macedo, G.A., da Graça Nascimento, M. and de Oliveira Carvalho, P., 2010. Aspergillus sp. lipase: potential biocatalyst for industrial use. Journal of molecular catalysis b: enzymatic, 67(3-4), pp.163-171.
[7]. Niaz M, Iftikhar T, Zia MA. Effect of nutritional factors on lipase biosynthesis by Aspergillus niger in solid state fermentation. Ext. J. App. Sci. 2013;1(1):9-16.

[8]. Mehta, A., Bodh, U. and Gupta, R., 2017. Fungal lipases: a review. Journal of Biotech Research, 8.

[9]. Balaji V, Arulazhagan P, Ebenezer P. Enzymatic bioremediation of polyaromatic hydrocarbons by fungal consortia enriched from petroleum contaminated soil and oil seeds. Journal of environmental biology. 2014 May 1;35(3):521-9.

[10]. Karigar CS, Rao SS. Role of microbial enzymes in the bioremediation of pollutants: a review. Enzyme research. 2011;2011.

[11]. Gopinath, S.C., Anbu, P., Lakshmipriya, T. and Hilda, A., 2013. Strategies to characterize fungal lipases for applications in medicine and dairy industry. BioMed research international, 2013.

[12]. Burkert J F M, Maugeri F and Rodrigues M I. “ Optimization of extracellular lipase production by Geotrichum sp. using factorial design". Bioresour Technol, 91 (2004): 77-84.

[13]. Sita kumara Karanam, Narasimha rao M. 2008. Enhanced lipase production by mutation induced Aspergillus japonicas, African journal of Biotechnology .7 (12),2008.

[14]. Iftikhar, T., Niaz, M., Abbas, S.Q., Zia, M.A., Ashraf, I., Lee, K.J. and Haq, I.U., 2010a. Mutation induced enhanced biosynthesis of lipases by Rhizopus oligosporus var. microsporus. Pak. J. Bot, 42(2), pp.1235-1249.

[15]. Beisson F, Tiss.A, Riviere .C, Verger.R. 2000. Methods for lipase detection and assay: a critical review. European Journal of lipid Science and Technology, Winheim, 133-153.

[16]. Lowry, O.H., Rosebrough, N.J., Farr, A.L. and Randall, R.J., 1951. Protein measurement with the phenol folin reagent. J Biol Chem, 193, pp.265-275. 
[17]. Laemmli .U.K. Cleavage of structural proteins during the assembly of head of bacteriophages T4, Nature, London, 227. 680-685, 1970.

[18]. Savitha, J, Srividya.S, Jagat .R, Payal.P, Priyanki, S, Rashmi,G.W, Roshini, K.T and Shantala.Y.M (2007). Identification of potential fungal strain(s) for the production of inducible, extracellular and alkalophiclipase. African journal of Bitechnology.6, 564-568.

[19]. B M Onyegeme-Okerenta, V I Okochi, S N Chinedu. Penicillin Production by Penicillium Chrysogenum PCL 501: Effect of UV Induced Mutation . The Internet Journal of Microbiology. 2013 Volume 12 Number 1.

[20]. John Geraldine Sandana Mala, Numbi R. Kamini, and Rengarajulu Puvanakrishnan. Strain improvement of Aspergillus niger for enhanced lipase production. J. Gen. Appl. Microbiol., 47, 181-186 (2001).

[21]. Babitha Bhaskaran1*, Sushmitha Shankar2 and Nagaraj Sonu. Genetic modification of Aspergillus niger by induced mutagenesis for lipase enzyme production. International journal of Life Sciences. Special Issue A 11: January 2018. 91-95.

[22]. Bapiraju,KVVSN, Sujatha.P, Ellaiah.P, Ramana T. Mutation induced enhanced biosynthesis of lipase. African Journal of Biotechnology. 3(1),618-621.

[23]. Ahmed M EL-Bondkly and Abeer A Keera ,2007.UV- and EMS-induced mutations affecting synthesis of alkaloid and lipase in Penicillium roquefortii. Arab journal of Biotechnology 10(2),241-248.

[24]. Ellaiah.P, T.Prabbhaker, B.Ramakrishna, A.Thaer Taleb, K. Adinarayana.2002. Strain improvement of Aspergillus niger for the production of liupase. Indian journal of Microbiology. 42 (2),151-154.

[25]. Saxena, R.K., Davidson, W.S., Sheoran, A. and Giri, B., 2003. Purification and characterization of an alkaline thermostable lipase from Aspergillus carneus. Process Biochemistry, 39(2), pp.239-247.

[26]. Kotogán, A., Németh, B., Vágvölgyi, C., Papp, T. and Takó, M., 2014. Screening for extracellular lipase enzymes with transesterification capacity in Mucoromycotina strains. Food Technology and Biotechnology, 52(1), pp.73-82.

[27]. Gombert A, Pinto A, Castilho L, Freire D. 1999. Lipase production by Penicillium restrictum in solid-state fermentation using babassu oil cake as substrate. Process Biochem. 35: 85-90.

[28]. Tang Lianghua, Xia Liming, Su Min, Guo Huaying. Purification and applications of a lipase from Penicillium expansum PED-03. Applied Biochemistry and Biotechnology. 142(2). 2007. 194-199.

[29]. Beatriz Ruiz, Amelia Farres , E.Langely, F.Masso, S.Sanchez, Purification and characterization of an extracellular lipase from Penicillium candidum. Lipids 36, 283 (2001).

[30]. Stocklein W, Sztajer H, Menge U, Schmid RD. Purification and properties of a lipase from Penicillium expansum. Biochimica et Biophysica Acta (BBA)-Lipids and Lipid Metabolism. 1993 Jun 12;1168(2):181-9.

[31]. Ferrer, M., Plou, F.J., Nuero, O.M., Reyes, F. and Ballesteros, A., 2000. Purification and properties of a lipase from Penicillium chrysogenum isolated from industrial wastes. Journal of Chemical Technology \& Biotechnology: International Research in Process, Environmental \& Clean Technology, 75(7), pp.569-576.

[32]. Dheeman DS, Antony-Babu S, Frías JM, Henehan GT. Purification and characterization of an extracellular lipase from a novel strain Penicillium sp. DS-39 (DSM 23773). Journal of Molecular Catalysis B: Enzymatic. 2011 Nov 1;72(3-4):256-62. 
[33]. Chahinian.H, Vanot.G, Ibrik.A, Rugani.N, Sarda L, Comeau LC, .Production of extracellular lipase by Penicillium cyclopium Purification and characterization of a partial acylglycerol lipase.2000. BioScienceBiotechologgy Biochemistry. 64(2): 215-222.

[34]. Miklos.T, Alexandra .K, Tamas.P, Shine .K, Naiyf.S.Alharbi, and Csaba.V. Purification and properties of extracellular lipase with tranesterification activity and 1,3Regioselectivity from Rhizomucor miehei and Rhizopus oryzae.i J.Microbiol.Biotechnol. (2017), 27(2). 277-288.

[35]. Namboodiri,VMH and Chattopadhyaya.R, 2000. Purification and Characterization of a novel thermostable lipase from Aspergillus niger. Lipids Champaign. 35(5):495-502.

\section{Cite this article as :}

Lakkakula. Bhagya Lakshmi, M. Raghu Ram, "Production, Purification and Characterization of Extracellular Lipase from a Mutated Strain of Penicillium Citrinum KU613360 ", International Journal of Scientific Research in Science and Technology (IJSRST), Online ISSN : 2395-602X, Print ISSN : 2395-6011, Volume 8 Issue 1, pp. 111-120, January-February 2021. Available at doi : https://doi.org/10.32628/IJSRST207697

Journal URL : http://ijsrst.com/IJSRST207697 